\title{
Epidemiology and Estimated Cost of Brachial Plexus Surgeries Performed through the Unified Health System in Brazil (2008-2016)
}

\section{Epidemiologia e estimativa de custo das cirurgias do plexo braquial realizadas pelo Sistema Único de Saúde no Brasil (2008-2016)}

\author{
Marcelo José Silva de Magalhães ${ }^{10} \quad$ Mariano Socolovsky $^{2}$ Mariana Mendes Araújo ${ }^{3}$ \\ Mariana Oliveira Silva ${ }^{3}$ Mayallu Almeida Mendes ${ }^{3}$ Pedro Augusto Costa ${ }^{3}$ Telma Soares Santos ${ }^{3}$ \\ ${ }^{1}$ Hospital Vila da Serra, Nova Lima, MG, Brazil \\ 2 Department of Neurosurgery, Hospital de Clínicas, Facultad de \\ Medicina, Universidad de Buenos Aires, Buenos Aires, Argentina \\ ${ }^{3}$ Faculdades Unidas do Norte de Minas, Montes Claros, MG, Brazil \\ Address for correspondence Marcelo José Silva de Magalhães, \\ MD, MSc, Rua Francisco Versiane Ataide, 760, apartamento \\ 1301., Montes Claros, MG, 39401-039, Brazil \\ (e-mail: marcelo7779@yahoo.com.br).
}

Arq Bras Neurocir 2020;39(4):243-248.

\begin{abstract}
Keywords

- epidemiology

- brachial plexus

- microsurgery

Introduction The brachial plexus is responsible for the innervation of the upper extremity of the body. About 10 to $20 \%$ of the peripheral nerve lesions are brachial plexus lesions.

Objective To describe the epidemiology of the brachial plexus microsurgery with exploration and neurolysis (BPMEN) and the brachial plexus microsurgery with nerve graft (BPMNG) performed through the Brazilian Unified Health System (SUS, in the Portuguese acronym) from 2008 to 2016.

Methodology A descriptive epidemiological study whose data were obtained from the Department of Informatics of the SUS (Datasus, in the Portuguese acronym). The study consisted of all patients submitted to BPMEN (code: 0403020034) and to BPMNG (code: 0403020042).

Result/Discussion A total of 5,295 procedures were performed with an annual incidence of 2.94/1 million inhabitants. The hospital expenses of these 2 codes totaled $\mathrm{R} \$ 4,492,603.88$ (US\$1,417,225.10). The BPMNG code presented an annual average of expenses with professional services of $R \$ 99,732.20$ (US\$ 31,461.26), and total expenses of $R \$ 897,589.83$ (US\$283,151.36). The amount transferred to the physician in this code in 2008 was $R \$ 294.56$ (US\$ 92.92), and currently it is $R \$ 441.84$ (US\$ 139.38). The BPMEN code presented an annual average of expenses of $R \$ 68,579.15$ (US\$ 21,633.80), with total expenses of $R \$ 617,212.40$ (US\$ 194,704.22). The amount transferred to the physician in this code in 2008 was $R \$ 153.44$ (US\$ 48.40), and currently it is $R \$ 230.16$ (US\$72.60). Both codes presented a lag in the transfer values to the physician that ranged from 16.55 to $17.64 \%$ when using the Brazilian national price index for the general consumer (IPCA, in the Portuguese acronym) as an inflation
\end{abstract}

received

October 15, 2017

accepted

November 13, 2017
DOI https://doi.org/

10.1055/s-0037-1613713. ISSN 0103-5355.
Copyright $(2020$ by Thieme Revinter

Publicações Ltda, Rio de Janeiro, Brazil
License terms

(c) (i) $\ominus$ (\$) 
Resumo

Palavras-chave
- epidemiologia
- plexo braquial
- microcirurgia parameter during the period studied. The mean number of hospitalization days for these 2 codes was 3.79 .

Conclusion The absence of deaths and the low rate of hospital stay confirm that the procedure is safe, with a low morbimortality rate. Both codes presented a lag in the transfer values to the physician at the end of the period.

Introdução O plexo braquial é responsável pela inervação da extremidade superior do corpo. Cerca de 10 a $20 \%$ das lesões dos nervos periféricos são lesões do plexo braquial. No Brasil, a maior parte dos procedimentos cirúrgicos é realizada pelo Sistema Único de Saúde (SUS), que é público e atende a toda a população.

Objetivo Descrever a epidemiologia dos procedimentos de microcirurgia do plexo braquial com exploração e neurólise (MPBEN) e microcirurgia do plexo braquial com microenxertia (MPBM) realizados pelo SUS no período de 2008 a 2016.

Metodologia Trata-se de um estudo epidemiológico descritivo, cujos dados foram obtidos pelo Departamento de Informática do SUS (Datasus). O estudo foi constituído por todos os pacientes submetidos a MPBEN (código: 0403020034) e a MPBM (código: 0403020042) em nossa instituição.

Resultado/Discussão Foram realizados 5.295 procedimentos com uma incidência anual de 2,94/1 milhão habitantes. Os gastos hospitalares desses dois códigos totalizaram $R \$ 4.492 .603,88$ (US\$ 1.417.225,10). O código de MPBEN apresentou uma média anual de gastos de $R \$ 68.579,15$ (US $\$ 21.633,80$ ), com um total de gastos de $R \$ 617.212,40$ (US\$194.704,22). O valor do repasse ao médico para esse código em 2008 era de $R \$ 153,44$ (US\$48,40), e atualmente é de $R \$ 230,16$ (US\$72,60). O código de MPBM apresentou uma média anual de gastos com serviços profissionais de $R \$$ 99.732,20 (US\$31.461,26), e um total de gastos de R\$897.589,83 (US\$283.151,36). O valor do repasse ao médico para esse código em 2008 era de $R \$ 294,56$ (US\$ 92,92), e atualmente é de $R \$ 441,84$ (US\$139,38). Ambos os códigos apresentaram uma defasagem dos valores dos serviços profissionais que oscilou entre 16,55 e 17,64\%, ao se utilizar o índice nacional de preços ao consumidor amplo (IPCA) como parâmetro de inflação durante o período estudado. Notou-se que a média de dias de internação desses 2 códigos foi de 3,79.

Conclusão A ausência de óbitos e a baixa taxa de permanência hospitalar atestam que o procedimento é seguro, com baixa taxa de morbimortalidade. Ambos os códigos apresentaram defasagem dos valores de repasse ao médico no final do período

\section{Introduction}

The brachial plexus is a complex network of nerves that is responsible for the innervation of the upper extremity of the body. It is formed in the posterior cervical triangle by the roots of $\mathrm{C} 5$ to $\mathrm{T} 1$ and it can receive contributions of $\mathrm{C} 4$ and $\mathrm{T} 2$ or not. ${ }^{1-3}$

American and European studies have shown that between 10 and $20 \%$ of peripheral nerve injuries are brachial plexus lesions, and that between 80 and $90 \%$ of these injuries are caused by automobile accidents. ${ }^{3}$

Brachial plexus injury is considered a devastating disease among adults, and characteristically entails a large socioeconomic impact in the lives of these patients. The real incidence of this type of trauma in Brazil is still unknown.

This incidence has probably increased in recent years with the increase in accidents involving motor vehicles of two wheels, mainly in large cities. ${ }^{4,5}$
Currently, there are few studies devoted to assessing the costs resulting from the surgical procedure of the patients with this type of injury. It is known that the treatment of brachial plexus lesions provides savings to the public budget. The results showed that the economy obtained with the surgical treatment of brachial plexus lesions may exceed $65 \%$ of the economic value of the welfare compensation that would have been attributed to the same patients if they had not undergone surgical treatment, as Felici et al demonstrated in 2014. ${ }^{5}$

The present study aims to characterize the epidemiological data related to the number of annual procedures, hospital and professional expenses, mean length of stay and number of deaths of patients admitted by the Brazilian Unified Health System (SUS, in the Portuguese acronym), and inflation impact on the costs of professional services in the 2008 to 2016 period, using the surgical codes microsurgery of the brachial plexus 
Table 1 Total number of hospitalizations for the procedures of brachial plexus microsurgery with exploration and neurolysis (code 0403020034 ) and micrografting of the brachial plexus with micrograft (code 0403020042) from 2008 to 2016, in the Brazilian Unified Health System

\begin{tabular}{|l|l|l|}
\hline Year & $\begin{array}{l}\text { Brachial plexus } \\
\text { microsurgery with } \\
\text { exploration and neurolysis }\end{array}$ & $\begin{array}{l}\text { Brachial plexus } \\
\text { microsurgery with } \\
\text { micrografting }\end{array}$ \\
\hline 2008 & 248 & 184 \\
\hline 2009 & 288 & 220 \\
\hline 2010 & 332 & 201 \\
\hline 2011 & 324 & 226 \\
\hline 2012 & 399 & 234 \\
\hline 2013 & 388 & 286 \\
\hline 2014 & 363 & 304 \\
\hline 2015 & 366 & 286 \\
\hline 2016 & 317 & 329 \\
\hline Total & 3,025 & 2,270 \\
\hline
\end{tabular}

with exploration and neurolysis (MPBEN) and microsurgery of the brachial plexus with micrografting (MPBM).

\section{Methodology}

This is a descriptive epidemiological study using data obtained through consultation with the database of the Department of Informatics of the SUS (Datasus, in the Portuguese acronym), at the electronic address http://www.datasus.gov.br, accessed in August 2017. In the present study, all cases of patients undergoing MPBEN (code: 0403020034) or MPBM (code: 040302 0042) were included in the period from January 2008 to December 2016. The tables were elaborated with data obtained from Datasus. It is important to emphasize that Datasus does not provide data regarding the specialty of the physician who performed the procedure. To calculate the inflation impact on the surgical codes during the study period, the national index of wide consumer prices (IPCA, in the Portuguese acronym) was considered. The IPCA was chosen because it is an index that covers families with monthly incomes comprised between 1 and 40 minimum wages, whatever the source of income, and residents in the urban areas of the regions. For the calculation of the IPCA, we used the program available online on the calculator platform of the Central Bank of Brazil (https:// www3.bcb.gov.br/CALCIDADAO/publico/exibirFormCorrecaoValores.do?method=exibirFormCorrecaoValores), in which it was possible to post the value to be corrected, specifying the time interval and the index to be used for correcting the values in Reais. ${ }^{6,7}$ For the conversion from Real to Dollar, we considered the quotation on August 12, 2017: R\$1 = U\$3.17.

It was not necessary to submit the project to the Research Committee, because it is a public domain database.

\section{Results}

-Table 1 contains the total number of hospitalizations for the MPBEN and MPBM codes occurring in the period from January 2008 to December 2016. The first code totaled 3,025 hospitalizations, and the second, 2,270, which, when added together, resulted in the amount of 5,295 procedures.

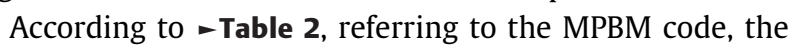
average cost of hospital services fluctuated from $\mathrm{R} \$$ $204,887.33$, lower annual cost in 2008, $\mathrm{R} \$ 381,803.57$, maximum annual value in 2016. An increase of $86.34 \%$ was evidenced in the costs during the study period. Hospital costs for this technique totaled $\mathrm{R} \$ 2,613,851.20$. It is important to mention that the expense of hospital service does not include the expense of the surgeon.

- Table 3, referring to the MPBEN code, revealed an increase of $69.46 \%$ in the costs of hospital services in Reais when compared to the annual minimum cost in 2008 to the annual maximum in 2013. The total value of hospital expenses in the period 2008 to 2016 was $R \$ 1,878,752.68$.

When comparing - Tables 2 and $\mathbf{3}$ in relation to the costs of hospital services, it is observed that the maximum annual

Table 2 Values in Reais and Dollars of hospital and professionals' expenses in brachial plexus microsurgery with micrografting (code 0403020042) from 2008 to 2016, in the unified Health system

\begin{tabular}{|c|c|c|c|c|}
\hline Year & $\begin{array}{l}\text { Hospital services } \\
\text { in Reais }\end{array}$ & $\begin{array}{l}\text { Hospital services } \\
\text { in Dollars }\end{array}$ & $\begin{array}{l}\text { Professionals services } \\
\text { in Reais }\end{array}$ & $\begin{array}{l}\text { Professionals services } \\
\text { in Dollars }\end{array}$ \\
\hline 2008 & $R \$ 204,887.33$ & US\$ $64,633.22$ & $R \$ 54,559.11$ & US\$ $18,157.44$ \\
\hline 2009 & $\mathrm{R} \$ 244,434.05$ & US\$ $77,108.53$ & $R \$ 64,803.20$ & US\$ $20,442.64$ \\
\hline 2010 & $R \$ 229,536.97$ & US\$ $72,409.13$ & $R \$ 59,206.56$ & US\$ $18,677.14$ \\
\hline 2011 & $R \$ 260,392.61$ & US\$ $82,142.77$ & $\mathrm{R} \$ 83,213.20$ & US\$ $26,250.22$ \\
\hline 2012 & $\mathrm{R} \$ 270,295.45$ & US\$ $85,266.70$ & $\mathrm{R} \$ 103,390.56$ & US\$ $32,615.31$ \\
\hline 2013 & $\mathrm{R} \$ 328,449.84$ & US\$ $103,611.93$ & $\mathrm{R} \$ 126,366.24$ & US\$39,863.20 \\
\hline 2014 & $R \$ 356,666.81$ & US\$ $112,513.18$ & $\mathrm{R} \$ 134,319.36$ & US\$ $42,372.03$ \\
\hline 2015 & $R \$ 337,384.61$ & US\$ $106,430.04$ & $\mathrm{R} \$ 126,366.24$ & US\$ $39,863.16$ \\
\hline 2016 & $\mathrm{R} \$ 381,803.57$ & US\$ $120,442.76$ & $R \$ 145,365.36$ & US\$ $45,856.58$ \\
\hline Total & $\mathrm{R} \$ 2,613,851.24$ & US\$ $824,558.73$ & $\mathrm{R} \$ 897,589.83$ & US\$ $283,151.36$ \\
\hline
\end{tabular}


Table 3 Values in Reais and Dollars of hospital and professionals' expenses in brachial plexus microsurgery with exploration and neurolysis (Code 0403020034) from 2008 to 2016, in the unified health system

\begin{tabular}{|c|c|c|c|c|}
\hline Year & $\begin{array}{l}\text { Hospital services } \\
\text { in Reais }\end{array}$ & $\begin{array}{l}\text { Hospital services } \\
\text { in Dollars }\end{array}$ & $\begin{array}{l}\text { Professionals services } \\
\text { in Reais }\end{array}$ & $\begin{array}{l}\text { Professionals services } \\
\text { in Dollars }\end{array}$ \\
\hline 2008 & $\mathrm{R} \$ 147,666.42$ & US\$ $46,582.46$ & $\mathrm{R} \$ 38,053.12$ & US\$ $12,004.13$ \\
\hline 2009 & $\mathrm{R} \$ 172,157.56$ & US\$ $54,308.37$ & $\mathrm{R} \$ 44,190.72$ & US\$ $13,940.29$ \\
\hline 2010 & $\mathrm{R} \$ 202,415.20$ & US\$ $63,853.37$ & $R \$ 50,942.08$ & US\$ $16,070.05$ \\
\hline 2011 & $R \$ 200,206.11$ & US\$ $63,156.50$ & $R \$ 62,143.20$ & US\$ $19,603.53$ \\
\hline 2012 & $\mathrm{R} \$ 242,145.98$ & US\$ $76,386.74$ & $\mathrm{R} \$ 91,833.84$ & US\$ $28,969.66$ \\
\hline 2013 & $\mathrm{R} \$ 250,235.72$ & US\$ 79,094.87 & $\mathrm{R} \$ 89,302.08$ & US\$ $28,171.00$ \\
\hline 2014 & $\mathrm{R} \$ 228,730.74$ & US\$ $72,154.80$ & $\mathrm{R} \$ 83,548.08$ & US\$ $26,355.61$ \\
\hline 2015 & $\mathrm{R} \$ 232,640.84$ & US\$ $73,388.27$ & $R \$ 84,238.56$ & US\$ $26,573.67$ \\
\hline 2016 & $\mathrm{R} \$ 202,554.11$ & US\$ $63,897.19$ & $\mathrm{R} \$ 72,960.72$ & US\$ $23,016.00$ \\
\hline Total & $R \$ 1,878,752.68$ & US\$ 592,666.43 & $\mathrm{R} \$ 617,212.40$ & US\$ $194.704,22194,704.22$ \\
\hline
\end{tabular}

expenditure with MPBM was R\$ 131,567.85, more costly than the maximum annual expenditure with MPBEN. Expenses with the costs of hospital services in these two procedures were $\mathrm{R} \$ 4,492,603.88$.

When assessing the value with professional services, it was noted that the MPBEN code presented an annual average of expenditures during the analyzed period of $R \$ 68,579.15$, with a total of expenses of $\mathrm{R} \$ 617,212.40$. This code presented the lowest expense with professional services in the year 2008 ( $R \$ 54,559.11)$ and the highest expenditure in 2016 ( $R \$ 145,365.36$ ). The value of the transfer of this SUS code to the surgeon in 2008 was $\mathrm{R} \$ 153.44$, and it is currently $\mathrm{R} \$ 230.16$. When correcting the value of this code by means of the actual inflation rate (IPCA) between January 2008 and December 2016, it should be $\mathrm{R} \$ 270.78$. Consequently, the lag of the value for this code is $17.64 \%$ (equivalent to $R \$ 40.62$ ) during the time interval studied.

On the other hand, the MPBM code presented an annual average of expenses with professional services of $R \$$ $99,732.20$ during that same period, with a total of expenses of $\mathrm{R} \$ 897,589.83$. This code presented the lowest expense in the year 2008 ( $R \$ 38,053.22$ ), and the highest expenditure in 2012 ( $R \$ 91,833.84)$. The value of the transfer of this SUS code to the surgeon in 2008 was $R \$ 294.56$, and it is currently $\mathrm{R} \$ 441.84$. When correcting the value of this code by the actual inflation rate (IPCA) between January 2008 and December 2016, it should be $\mathrm{R} \$ 514.98$ at the end of the period. The value lag for this code was $16.55 \%$ (equivalent to $\mathrm{R} \$ 73.14$ ) during the time interval of the present study.

The mean length of hospital stay of the patients is shown in - Tables 4 and $\mathbf{5}$. With the MPBM code (-Table 5), it was noted that the average permanence during the 9 years analyzed was 3.92 days, higher than the average with the MPBEN code, which was 3.67 days. Only in the years 2008 and 2011 the mean length of hospital stay was higher with the MPBEN code.

There was no death rate in any of the years in both techniques, and for this reason this was not recorded in the table.
Table 4 Mean length of hospital stay in microsurgery of the brachial plexus with micrografting (code 0403020042) from 2008 to 2016, in the Brazilian Unified Health System

\begin{tabular}{|l|l|}
\hline Year & Mean stay (days) \\
\hline 2008 & 3.8 \\
\hline 2009 & 4.2 \\
\hline 2010 & 4.1 \\
\hline 2011 & 3.8 \\
\hline 2012 & 4.0 \\
\hline 2013 & 3.7 \\
\hline 2014 & 4.0 \\
\hline 2015 & 3.9 \\
\hline 2016 & 3.8 \\
\hline
\end{tabular}

Table 5 Mean length of hospital stay in brachial plexus microsurgery with exploration and Neurolysis (Code 0403020034) from 2008 to 2016 in the Brazilian Unified Health System

\begin{tabular}{|l|l|}
\hline Year & Mean stay (days) \\
\hline 2008 & 3.9 \\
\hline 2009 & 3.6 \\
\hline 2010 & 3.7 \\
\hline 2011 & 3.9 \\
\hline 2012 & 3.4 \\
\hline 2013 & 3.7 \\
\hline 2014 & 3.7 \\
\hline 2015 & 3.8 \\
\hline 2016 & 3.4 \\
\hline
\end{tabular}

\section{Discussion}

In Brazil, a study conducted at the Federal District, involving 35 patients, demonstrated that most brachial plexus lesions were located in the supraclavicular region (62\%), being 21 (60\%) traction mechanism injuries, 9 (25\%) by firearm projectile, 3 
(8.5\%) compression, and 2 (5.7\%) sharp wounds. ${ }^{8}$ Motorcycle accidents accounted for $54 \%$ of the causes of trauma with radicular avulsion in $76 \%$ of the cases. ${ }^{8}$ Another study conducted in Belo Horizonte involved 47 patients undergoing surgery for the treatment of brachial plexus injury that were retrospectively evaluated in the period from 2010 to $2011 .^{9}$ In this study, $91.5 \%$ of the patients were males, with a mean age of 34.4 years. Traffic accidents were the main causes of trauma (97.9\%), and motorcycle accidents were responsible for $68.1 \%$ of the injuries. ${ }^{9}$ The mean time between the specialized consultation and the surgical treatment was 10 months. ${ }^{9}$

In a study conducted in the city of São Paulo, in the period between 2004 and 2012, involving 406 patients with brachial plexus injury, $94.6 \%$ were males, and motorcycle accidents were responsible for $79 \%$ of the cases. ${ }^{10}$ It was observed that most of the lesions occurred in the supraclavicular region, with patients in this study with a mean age of 28.38 years. The complete type lesions occurred in $46.1 \%$ of the cases, $30.1 \%$ compromised the spinal nerves C5-C6, 20.9\% were lesions with C5-C6-C7 pattern, and 2.9\% were lesions involving the C8-T1 spinal nerves. ${ }^{10}$

The Brazilian population presented an increase of $14,280,000$ inhabitants during the study period, between 2008 and 2016. In 2008, Brazil's population was estimated at 191.8 million inhabitants. It is observed that the annual incidence of surgical procedures considering the codes of MPBM (code: 0403020034) and of MPBEN (code: 0403020042) in 2008 , there were 2.25 procedures/ 1 million inhabitants. Subsequently, in 2016, the annual incidence was 3,13 procedures/1 million inhabitants, when the population was $206,080,000$ inhabitants. It is noted that the highest incidence of procedures occurred in 2013, with 3,36/1 million inhabitants. A study by Flores identified an estimated incidence of 1.75 cases/100 thousand inhabitants/year in the region of the Federal District between the years 2004 and $2005 .^{8}$

An international study conducted in 2010 in a trauma center in New Delhi, India, followed 69 hospitalized patients aged between 11 and 55 years old (mean age of 24.6 years old), all males and with different degrees of brachial plexus injury. The average hospital stay was 14 days, varying from 2 to 43 days. It was noted that the average of days of hospital stay in Brazil according to the present study was 3.79. Of the 69 patients in the Indian study, 60 (87\%) were submitted to surgical intervention and presented average permanence in the hospital of 12 days, and the mean postoperative stay was 2 days. The average preoperative expenditures were 43,117.75 Indian rupees per patient, and postoperative expenditures had an average of 6,449.14 Indian rupees per patient. The other 9 patients (13\%) opted for conservative treatment after a period of waiting and counseling that lasted on average 6 days and cost the hospital an average of 25,147.61 Indian rupees per patient, which corresponds to US\$503.00. The total hospital expense with 69 patients was 3,588,402.00 Indian rupees, which corresponds to U\$71,774.86. ${ }^{11}$

It is important to mention that the economy obtained through surgical treatment of brachial plexus lesions may exceed $65 \%$ of the economic value of the compensation that would have been attributed to the same patients if they had not undergone surgical treatment, as Felici et al demonstrated in $2014 .^{5}$

The technique with micrografting was used more in 2016 and presented an increment of $78 \%$ when compared with the year 2008. The technique with exploration and neurolysis, in turn, was more performed in 2012, with an increase of $27.8 \%$ when compared with 2008 and 2016. It is perceived, therefore, that the technique with micrografting was progressively more used over these years. It is unclear what caused the MPBM code to present an increase in its realization. There are some possibilities, such as the greater preparation of surgeons over the period studied, since the micrografting is technically more complex than simple exploration and neurolysis. Another possibility that could perhaps justify the raise in use of the MPBEN code is that it has the highest value honorarium compared with isolated neurolysis.

The main limitation of the present study was not including data from the complementary health system, of restricted access in comparison with SUS information. In addition, there is a notorious scarcity of national and global epidemiological contents related to the incidence and prevalence of brachial plexus lesions. Another possible setback of this work was the probability of multiple and/or erroneous diagnoses being included in the results found at Datasus.

\section{Conclusion}

The absence of deaths and the low rate of hospital stay show that the MPBEN and MPBM codes are safe, with low morbidity and mortality rates. Both codes present a lag of the pass values to the physicians in the end of the period. Studies that include data from the complementary health system will be important for complementing the data in the present study.

Conflict of Interests

The authors have no conflict of interests to declare.

\section{References}

1 Sakellariou VI, Badilas NK, Mazis GA, et al. Brachial plexus injuries in adults: evaluation and diagnostic approach. ISRN Orthop 2014; 2014:726103

2 Bhandari PS, Maurya S. Recent advances in the management of brachial plexus injuries. Indian J Plast Surg 2014;47(02): 191-198

3 Rezende MR, Silva GB, Paula EJ, Mattar Junior R, Camargo OP. What has changed in brachial plexus surgery? Clinics (São Paulo) 2013; 68(03):411-418

4 Sinha S, Khani M, Mansoori N, Midha R. Adult brachial plexus injuries: Surgical strategies and approaches. Neurol India 2016; 64(02):289-296

5 Felici N, Zaami S, Ciancolini G, Marinelli E, Tagliente D, Cannatà C. Cost analysis of brachial plexus injuries: variability of compensation by insurance companies before and after surgery. Handchir Mikrochir Plast Chir 2014;46(02):85-89

6 Sistema Nacional de Índices de Preços ao Consumidor. Available at: http://www.ibge.gov.br/home/estatistica/indicadores/precos/in pc _ipca/defaultinpc.shtm. Acessed in June 152017

7 BCB-Calculadora do cidadão- Banco Central. Avalilable at: https://www3.bcb.gov.br/CALCIDADAO/publico/exibirFormCorrecaoValores.do?method1/4exibirFormCorrecaoValores. Acessed in June 152017 
8 Flores LP. Estudo epidemiológico das lesões traumáticas de plexo braquial em adultos. Arq Neuropsiquiatr 2006;64(01):88-94

9 Oliveira CM, Malheiro JA, Moreira LA, et al. Perfil epidemiológico das lesões traumáticas do plexo braquial em adultos atendidos em ambulatório de referência em Minas Gerais. Arq Bras Neurocir 2016;35:193-196
10 Faglioni W Jr, Siqueira MG, Martins RS, Heise CO, Foroni L. The epidemiology of adult traumatic brachial plexus lesions in a large metropolis. Acta Neurochir (Wien) 2014;156(05):1025-1028

11 Pandey N, Gupta D, Mahapatra A, Harshvardhan R. Bed wise cost analysis of in-patient treatment of brachial plexus injury at a Level I trauma Center in India. Asian J Neurosurg 2014;9(02):89-92 